Yüzüncü Y1 Üniversitesi
Tarim Bilimleri Dergisi

Research Article (Araştırma Makalesi)

Effects of Endophytic Bacteria on Some Physiological Traits and Nutrient Contents in Pepper Seedlings under Drought Stress**

\author{
Aynur SADAK ${ }^{*}$, Ahmet AKKOPRU ${ }^{2}$, Suat SENSOY ${ }^{3}$ \\ ${ }^{1,3}$ Horticulture Sci., Institute of Natural Sciences, Van Yuzuncu Yil University, 65080 Van, Turkey \\ ${ }^{2}$ Department of Plant Protection, Agriculture Faculty, Van Yuzuncu Yil University, 65080 Van, Turkey \\ ${ }^{3}$ Department of Horticulture, Agriculture Faculty, Van Yuzuncu Yil University, 65080 Van, Turkey \\ ${ }^{1}$ https://orcid.org/0000-0002-5865-6497 htps://orcid.org/0000-0002-1526-6093 ${ }^{3}$ https://orcid.org/0000-0001-7129-6185 \\ Corresponding author's e-mail: aynuursadak@gmail.com
}

\section{Article Info}

Received: 29.12.2020

Accepted: 27.02.2021

Online Published 30.03.2021

DOI: 10.29133 /yyutbd.849260

Keywords

Drought,

EB,

Enzyme activity,

Growth,

Mineral matters,

Pepper.

\begin{abstract}
The present study was conducted to determine the effects of the endophytic bacteria (EB) on some physiological traits and nutrient contents in pepper (Capsicum annuum L.) seedlings grown under drought stress. The pepper cv. Mostar $\mathrm{F}_{1}$ and two EB isolates [Bacillus thurigiensis (CA41/1) and Ochrobactrum sp. (CB36/1)] were employed under drought stress condition. The first EB application was at a density of $10^{8} \mathrm{CFU} \mathrm{mL}^{-1}$ as $10 \mathrm{~mL}$ plant ${ }^{-1}$ at the first cotyledon leaf stage and the second one was two weeks later. The seedlings were irrigated by gravimetric method on a regular basis every two days. Twenty days after EB application, irrigation was terminated completely in half of the applications in order to form drought stress for 7 days. Among the studied traits, membrane damage index, leaf relative water content, amount of malondialdehyde, catalase enzyme activity, ascorbate peroxidase enzyme activity, and the contents of some mineral elements (K, Ca and $\mathrm{Mg}$ ) were significantly different in drought stressed seedlings compared the control (regularly irrigated) seedlings. EB (Especially CA41/1) had generally positive effects on most studied traits, whereas drought stress had generally negative effects on the mentioned traits. There might be a high potential of EB fighting against drought stress in pepper; however, one keeps in mind that there is variation in the performance of EB; therefore, the best EB combinations have to be determined even for cultivars in each plant species in future studies.
\end{abstract}

\title{
Endofitik Bakterilerin Kuraklık Stresi Altındaki Biber Fidelerinin Bazı Fizyolojik Özellikleri ve Besin İçerikleri Üzerine Etkileri
}

\section{Makale Bilgileri}

Geliș: 29.12.2020

Kabul: 27.02.2021

Online Yayınlanma 30.03.2021

DOI: $10.29133 /$ yyutbd.849260

\section{Anahtar kelimeler}

Biber,

EB'ler,

Enzim aktivitesi,

Büyüme,
Öz: Bu çalışma, kuraklık stresi altında yetiştirilen biber (Capsicum annuum L.) fidelerinde endofitik bakterilerin (EB) bazı fizyolojik özellikler ve besin içerikleri üzerine etkilerini belirlemek amacıyla yapılmıştır. Mostar $F_{1}$ Biber çeşidi, iki EB izolat1 [Bacillus thurigiensis (CA41 / 1) ve Ochrobactrum sp. (CB36 / 1)] kuraklık stresi altında kullanılmıştır. İlk EB uygulaması, ilk kotiledon yaprağı aşamasında $10 \mathrm{~mL} /$ bitki olarak $10^{8} \mathrm{CFU} / \mathrm{mL}$ yoğunlukta ve ikincisi ise iki hafta sonra yapılmıştır. Fideler, iki günde bir düzenli olarak gravimetrik yöntemle sulanmıştır. EB uygulamasından yirmi gün sonra, 7 günlük kuraklık stresi oluşturmak için uygulamaların yarısında sulamaya tamamen son verilmiştir. Çalışılan özellikler arasında, kuraklık stresi altındaki fidelerde kontrol (düzenli olarak sulanan) fideler ile karşılaştırıldığında, membran zararlanma indeksi, yaprak oransal su içeriği, malondialdehit miktarı, katalaz enzim aktivitesi, 
Kuraklık, Mineral maddeler. askorbat peroksidaz enzim aktivitesi ve bazı mineral elementlerin içerikleri $(\mathrm{K}$, $\mathrm{Ca}$ ve $\mathrm{Mg}$ ) önemli ölçüde farklı bulunmuştur. EB'ler (Özellikle CA41 / 1), incelenen özelliklerin çoğunda genel olarak olumlu etkilere sahipken, kuraklık stresi belirtilen özellikler üzerinde genellikle olumsuz etkilere yol açmıştır. Biberde kuraklık stresine karşı savaşan yüksek bir EB potansiyeli olabilir; ancak, EB'lerin performansında farklılıklar olduğu unutulmamalıdır; bu nedenle, en iyi EB kombinasyonları, gelecekteki çalışmalarda her bitki türündeki çeşitler için belirlenmelidir.

**This article extracted from M.Sc. thesis of Aynur Sadak.

\section{Introduction}

The need for water in agriculture is indispensable and vegetables need high amount of irrigation water (Sensoy et al., 2007). The world is threatened by global warming and climate change. This climate change causes several stress factors in agricultural areas. These stress conditions also constitute drought stress (Turkes et al., 2000; Ozturk, 2002). Plants experience different biotic or abiotic stress conditions for the duration of their life cycle. Drought stress is a common abiotic stresses disturbing plant growth and yield (Kabay and Sensoy, 2016, 2017; Kusvuran and Dasgan, 2017; Cakmakci et al., 2017; Ekinci and Başbağ, 2019; Söylemez et al., 2020). Drought stress occurs by irregular rainfalls accompanied by extreme wind and extreme temperatures (Ozturk, 2002). As a result of the increase in the world population, it is seen that water consumption increases and climate change such as global warming cause the water to decrease gradually (Çakmakc1 et al., 2016; Sahin et al., 2016).

It is known that some biostimulant applications give positive results in abiotic stress conditions (Turkmen et al., 2005). Plant growth promoting rhizobacteria and a recent focus within this bacteria group of endophytic bacteria, have also significant potential. Endophytic bacteria (EB) have plant growth promoting effect that is EB have a vegetative and generative growth-enhancing effect in varying proportions in plants (Akkopru et al., 2018). EB reside in the internal plant tissues and do not have deleterious effects on the plant (Rosenblueth and Martínez-Romero, 2006; Hardoim et al., 2008).

EB might affect plant growth directly or indirectly. EB might also produce the plant growth hormones (Van Loon, 2007). Moreover, EB cause reduction in ethylene synthesis, convert mineral matters into much useful forms and stimulate plant defense mechanisms (Saharan and Nehra, 2011). EB might also play a role as a biocontrol agent reducing the efficacy and quantity of pathogens, encouraging beneficial symbiotic relationships or decomposing xenobiotics found in soil (Saharan and Nehra, 2011). EB colonization is not restricted to a certain region of the plant and the effects of EB might be ameliorated by plant transport system (Rosenblueth and Martínez- Romero, 2006; Hardoim et al., 2008). The interior tissues of the plant might be protected by EB from biotic and abiotic stress factors (Rosenblueth and Martínez-Romero, 2006).

The pepper which is an important vegetable crop worldwide and contains a wide genetic variability (Aktas et al., 2009), is affected severely by biotic and abiotic stress conditions. Pepper is also very susceptible to drought stress (Yildirim et al., 1994; Dagdelen et al., 2004; Ertek et al., 2007). EB might help pepper seedlings to lessen drought stress. The study was carried out to determine the effects of the endophytic bacteria (EB) on the growth of the pepper (Capsicum annuum L.) seedlings developed under drought stress.

\section{Material and Methods}

The pepper cv. Mostar F1 was employed as plant material and two bacteria isolates [Bacillus thurigiensis (CA41/1) and Ochrobactrum sp. (CB36/1)] whose PGPR activities previously determined (Ozaktan et al., 2015) were used as biological control agents. The study was carried out with randomized plots with three replications. There were 6 applications of EB and drought applications (1: control, 2: drought, 3: CA41/1, 4: CA41/1+drought, 5: CB36/1 and 6: CB36/1+drougt applications) with 3 replications each having 5 pots and 1 plant per pot ( $2 \mathrm{~L}$ pots filled with 1 peat: 1 perlite). The pepper seeds were sown in a growth chamber at a $70 \%$ relative humidity and a temperature of $24 \pm 1^{\circ} \mathrm{C}$ with $14 \mathrm{~h}$ fluorescent illumination (approximately $8000 \mathrm{~lx}$ light intensity). 


\subsection{PGPR applications}

EB applied to seedlings as: 48-hour EB cultures developed on King's B medium (Pepton $20 \mathrm{~g}$ $\mathrm{L}^{-1}, \mathrm{~K}_{2} \mathrm{HPO}_{4} 1.5 \mathrm{~g} \mathrm{~L}^{-1}, \mathrm{MgSO}_{4} 7 \mathrm{H}_{2} \mathrm{O} 1.5 \mathrm{~g} \mathrm{~L}^{-1}$, Glycerol $10 \mathrm{ml} \mathrm{L}^{-1}$, Agar $15 \mathrm{~g} \mathrm{~L}^{-1}$ ) were prepared in suspension with $10^{8}$ colony-forming units (CFU) $\mathrm{mL}^{-1}$ density (Ozaktan et al., 2015). The suspensions were applied twice to the seedlings by drenching method with $10 \mathrm{ml} \mathrm{plant}^{-1}$, the first EB application was performed when the first true leaves began to open, and the second one was two weeks later.

\subsection{Drought stress}

During the experiment period, the seedlings were irrigated by gravimetric method on a regular basis every two days. The experiment was terminated after 8 weeks. The field capacity was determined by taking the weight of the pots in the first seed sowing. With an equal amount of tap water regularly was applied every two days to all the pots. All seedlings were irrigated with equal amount of water for 7 weeks after seed sowing. For the last week, control plants was irrigated to field capacity and for drought stress irrigation was completely stopped (Kusvuran, 2010; Kabay, 2014).

\subsection{Determination of leaf water content}

To determine the proportional water content of leaf samples taken from plants at the $8^{\text {th }}$ week, fresh leaf samples were weighed (FW) and held in distilled water for $4 \mathrm{~h}$ to determine the turgor weights (TW); then, the samples were held in an oven $\left(65^{\circ} \mathrm{C}\right)$ for $48 \mathrm{~h}$ and weighted (DW). Leaf water content was determined as (Kusvuran, 2010; Kabay et al., 2017):

$\mathrm{LWC}=(\mathrm{FW}-\mathrm{DW}) /(\mathrm{TW}-\mathrm{DW}) \mathrm{x} 100 \mathrm{FW}$

\subsection{Membrane damage index}

After the application of EB and drought, the disc-shaped leaf samples in $17 \mathrm{~mm}$ diameter were obtained from the $3^{\text {rd }}$ leaves of pepper seedlings, incubated for $5 \mathrm{~h}$ in $10 \mathrm{~mL}$ distilled water, and the EC values were determined. The same disc samples were held at $100{ }^{\circ} \mathrm{C}$ for $10 \mathrm{~min}$, and their EC values were determined again. Membrane Damage Index (MDI) was determined as (Dlugokecka and Kacperska-Palacz, 1978; Fan and Blake, 1994; Kusvuran, 2010).

\subsection{Malondialdehyde (MDA) product of lipid peroxidation in plants}

$0.5 \mathrm{~g}$ of leaf samples were homogenized with $10 \mathrm{ml}$ of $0.1 \%(\mathrm{w} / \mathrm{v})$ tri-chloro-acetic acid and the homogenate was centrifuged at $15000 \mathrm{rpm}$ for $5 \mathrm{~min} .1 \mathrm{~mL}$ of the supernatant was added with $0.5 \%$ of thio-barbituric-acid dissolved in $4 \mathrm{~mL} 20 \%$ tri-chloro-acetic acid. The mixture was incubated at $95{ }^{\circ} \mathrm{C}$ for $30 \mathrm{~min}$ and immediately cooled in ice bath; then centrifuged at $10000 \mathrm{rpm}$ for $10 \mathrm{~min}$ and absorbance readings were accomplished for the supernatant at 532 and $600 \mathrm{~nm}$ wavelengths. The content of MDA was determined according to the following equation (Heath and Packer, 1968; Sairam and Saxena, 2000).

\subsection{Antioxidative enzyme analyses}

The frozen $1 \mathrm{~g}$ leaf sample (third leaf from the bottom of the plants) was homogenized ( $4{ }^{\circ} \mathrm{C}$ for 30 minutes at $18000 \mathrm{rpm}$ ) with a mixture of $5 \mathrm{ml}$ of cold $0.1 \mathrm{M}$ Na-phosphate, $0.5 \mathrm{mM}$ Na-EDTA and $1 \mathrm{mM}$ ascorbic acid (pH: 7.5). The ascorbate peroxidase (APX) activity was determined immediately in the homogenate with this preparation. The frozen $1 \mathrm{~g}$ leaf sample (third leaf from the bottom of the plants) was homogenized $\left(4^{\circ} \mathrm{C}\right.$ for $30 \mathrm{~min}$ at $18000 \mathrm{rpm}$ ) with $5 \mathrm{ml}$ of cold $0.1 \mathrm{M}$ Na-phosphate, 0.5 mM Na-EDTA mixture (pH: 7.5). Catalase activity (CAT) activity was detected in the homogenate (Jebara et al., 2005; Guneri Bagci, 2010; Kabay, 2014; Guzel et al. 2018). CAT activity was detected by monitoring the disappearance of $\mathrm{H}_{2} \mathrm{O}_{2}$ at a wavelength of $240 \mathrm{~nm} .0 .05 \mathrm{M}$ phosphate buffer $\left(\mathrm{KH}_{2} \mathrm{PO}_{4}\right), 1.5 \mathrm{mM} \mathrm{H}_{2} \mathrm{O}_{2}$ mixture (pH: 7.0) was employed as the reaction solution. $2.5 \mathrm{~mL}$ of reaction solution and $0.2 \mathrm{ml}$ of plant extract were mixed. In spectrophotometer, $0^{\text {th }}$ and $60^{\text {th }}$ seconds readings 
were observed at $240 \mathrm{~nm}$ wavelength. The reaction was initiated by the addition of $0.1 \mathrm{~mL}$ enzyme extract. The evaluation was completed based on the change in absorbance within 1 min (Jebara et al., 2005; Guneri Bagci, 2010; Kabay, 2014). Ascorbate peroxidase (APX) activity was detected at $290 \mathrm{~nm}$ depending on the ascorbic acid reducing $\mathrm{H}_{2} \mathrm{O}_{2}$. As the reaction solution, $50 \mathrm{mM}$ phosphate buffer $\left(\mathrm{KH}_{2} \mathrm{PO}_{4}\right), 0.5 \mathrm{mM}$ ascorbic acid, $0.1 \mathrm{mM}$ EDTA, $1.5 \mathrm{mM} \mathrm{H}_{2} \mathrm{O}_{2}$ mixture (pH: 7.0) were employed. 3 $\mathrm{mL}$ of reaction solution and $0.1 \mathrm{~mL}$ of plant extract were mixed. The $0^{\text {th }}$ and $60^{\text {th }}$ seconds readings were taken at $290 \mathrm{~nm}$ wavelength in the spectrophotometer. The reaction was started by the addition of 0.1 $\mathrm{ml}$ enzyme extract. The evaluation was completed based on the change in absorbance within 1 min (Jebara et al., 2005; Guneri Bagci, 2010; Kabay, 2014).

\subsection{Mineral element analysis}

The mineral matter contents of the shoot samples from the applications were determined in an atomic absorption device (Thermo no: ice3000) (Kacar, 1994; Kacar and Inal, 2008). The mineral matter contents having significant results such as $\mathrm{Mg}, \mathrm{K}$, and Ca were presented in the results.

\subsection{Statistical analysis}

To determine the effect of stress in drought and control plants according to the experimental design of randomized plots, the data statistically analyzed by using package program IBM SPSS Statistics 21.0 were used. The $t$ test was used to compare the drought application means, and the Duncan test was used to compare the application means of EB and interactions.

\section{Results and Discussion}

The effect of EB on growth of pepper seedlings grown under drought stress was studied and the obtained results were presented below (Tables 1-3). Drought stress negatively affected pepper seedlings growth. In general, EB application positively influenced drought-stressed pepper seedlings (Table 1-3). For the membrane damage index (MDI), it was determined that pepper seedlings inoculated with EB had lower membrane damage index values compared to the control application (Table 1). EB application CB36/1 (Ochrobactrum sp.) had $65.74 \%$ (10.07) lower MDI value compared to control application (29.39). Moreover, the other EB application [Bacillus thurigiensis (CA41/1)] had also $47.09 \%$ (15.55) lower MDI value compared to control application (29.39). It is known that the free radical structures formed by stress in the plants damage the membrane structure and harms the membrane permeability (Shewfelt and Purvis, 1995). For leaf water content (LWC), although there were no significant differences among the applications, there was up to $2.87 \%$ increase in LWC at EB applications (from 86.46 to 88.95). It has been reported that PGPR applications decrease the membrane damage in plants in drought stress conditions by increasing the synthesis of proline and by protecting the water status in the cell (Ansary et al., 2012; Chakraborty et al., 2013; Sarma and Saikia, 2014). Pepper is an important vegetables species in the world and Turkey. Water stress conditions adversely affect pepper seedlings sensitive to drought stress or water restriction (Yildirim et al., 1994; Ozturk, 2002; Dagdelen et al., 2004). Drought stress also negatively affects cv. Mostar F1 pepper. It has been reported that some endophyte bacteria on the seedlings of cv. Mostar F1 on post-stress recovery are relatively promising in seedlings exposed to drought stress (Sadak et al., 2019).

Table 1. Membrane damage index and leaf water content and of drought stressed EB applications

\begin{tabular}{lcc}
\hline & Leaf Water Content (\%) & Membrane Damage Index (\%) \\
\hline EB & Drought application & Drought application \\
\hline Control & $86.46 \pm 17.10^{\mathrm{ns}}$ & $29.39 \pm 6.82 \mathrm{~A} * *$ \\
CB36/1 & $88.95 \pm 11.42$ & $10.07 \pm 3.11 \mathrm{C}$ \\
CA41/1 & $88.10 \pm 16.23$ & $15.55 \pm 4.25 \mathrm{~B}$ \\
\hline Mean & $87.70 \pm 14.91$ & $18.34 \pm 4.72$ \\
\hline & & \\
ns: non-significant. & & \\
A-C: Means in the same column not sharing the same superscript are significantly different $(* * p<0.01)$.
\end{tabular}


The response of MDA content and antioxidant enzyme activities (CAT and APX) have been presented in Table 2. MDA content of the drought stressed pepper seedlings increased $248.77 \%$ (13.16) compared the control seedlings (5.19). There were insignificant increases in MDA contents of EB inoculated seedlings. There were also increases in CAT and APX contents of EB inoculated seedlings. However, only CA41/1 (Bacillus thurigiensis) caused significant increases in CAT and APX contents compared to control application (0.110 and 3.03, respectively) by $218.18 \%(0.240)$ and $131.68 \%$ (3.99), respectively. In a study dealing with drought stress in common bean, it was reported that there were increases in MDA level and CAT, SOD and APX activities (Kabay and Sensoy, 2017). In another study conducted in beans, MDA content is reported to increase in plants with drought stress (Kusvuran and Dasgan, 2017). It is obvious that antioxidant enzyme activity plays an important role in increasing tolerance to drought stress in plants. The antioxidant enzyme activity could reduce the negative effects of free radicals, especially in stress conditions. In recent studies, it is stated that with the increasing use of PGPRs in arid conditions, tolerance can be achieved by increasing antioxidant enzyme activity against the negative effects of stress (Sarma and Saikia, 2014). Kohler et al. (2008) reported that the antioxidant enzyme level was increased, and therefore, the tolerance to stress was increased in drought stressed lettuce inoculated with Pseudomonas mendocina. It was also stated that mung bean inoculated with Pseudomonas aeruginosa improved the activity of SOD and CAT; this might contribute to increase the tolerance to stress (Sarma and Saikia, 2014). Kumari et al. (2018) reported three isolates expect one strain showed positive response for CAT and PGPR with CAT activity have been stated to defend plants against biotic stress agents by maintaining plant ROS levels.

Table 2. CAT, APX and MDA values obtained in drought and EB applications

\begin{tabular}{|c|c|c|c|}
\hline \multicolumn{4}{|c|}{ CAT (nmol g-1 FW) } \\
\hline EB & Control & Drought & Mean \\
\hline Control & $0.063 \pm 0.011$ ns & $0.157 \pm 0.082$ & $0.110 \pm 0.046 \mathrm{~B} * *$ \\
\hline CB36 / 1 & $0.157 \pm 0.025$ & $0.125 \pm 0.036$ & $0.141 \pm 0.030 \mathrm{~B}$ \\
\hline CA41 / 1 & $0.250 \pm 0.096$ & $0.230 \pm 0.016$ & $0.240 \pm 0.056 \mathrm{~A}$ \\
\hline Average & $0.156 \pm 0.0688^{\mathrm{ns}}$ & $0.170 \pm 0.123$ & \\
\hline \multicolumn{4}{|c|}{$\operatorname{APX}\left(\mathrm{nmol} \mathrm{g}^{-1} \mathrm{FW}\right)$} \\
\hline EB & Control & Drought & Mean \\
\hline Control & $2.51 \pm 0.65$ c * & $3.55 \pm 0.72$ bc & $3.03 \pm 0.68 \mathrm{~B} * *$ \\
\hline CB36 / 1 & $2.99 \pm 0.82$ bc & $3.89 \pm 0.83 \mathrm{~b}$ & $3.44 \pm 0.82$ B \\
\hline CA41 / 1 & $2.95 \pm 0.76 \mathrm{bc}$ & $5.03 \pm 0.96 \mathrm{a}$ & $3.99 \pm 0.86 \mathrm{~A}$ \\
\hline Average & $2.82 \pm 0.74 \mathrm{~B}^{* *}$ & $4.15 \pm 0.83 \mathrm{~A}$ & \\
\hline \multicolumn{4}{|c|}{ MDA (nmol / g TA) } \\
\hline EB & Control & Drought & Mean \\
\hline Control & $4.45 \pm 1.23^{\mathrm{ns}}$ & $11.29 \pm 2.96$ & $7.87 \pm 2.09 \mathrm{~ns}$ \\
\hline CB36 / 1 & $6.62 \pm 2.06$ & $13.74 \pm 3.01$ & $9.47 \pm 2.53$ \\
\hline CA41 / 1 & $4.52 \pm 1.26$ & $14.45 \pm 2.49$ & $8.49 \pm 1.87$ \\
\hline Average & $5.19 \pm 1.51 \mathrm{~B}^{* *}$ & $13.16 \pm 2.82 \mathrm{~A}$ & \\
\hline
\end{tabular}

There were also significant differences of the applications on $\mathrm{Mg}, \mathrm{K}$, and Ca contents of pepper seedlings (Table 3). Potassium (K) content of the drought stressed pepper seedlings decreased approximately $18 \%$ (2992 ppm) compared the control seedlings (3641 ppm). There were increases in Ca content of EB inoculated seedlings. However, only CA41/1 (Bacillus thurigiensis) inoculated applications caused significant increases in Ca content compared to control application and CB36/1 (Ochrobactrum sp.) by $49 \%$ (6891 ppm) and $41.6 \%$ (5941 ppm) respectively. These reactions at drought condition, the pepper plants inoculated with CA41/1 were more effective in the Mg content when compared to the plants that were un-inoculated. Kabay and Sensoy, (2016 and 2017) and Kabay et al. (2017) also reported reduction in $\mathrm{K}, \mathrm{Ca}$, and $\mathrm{Mg}$ contents due to abiotic stress conditions. 
Mechanisms for the closure of stomata in plants under water stress conditions are related with the amount of $\mathrm{K}^{+}$ion, the accumulation of ABA hormone and turgor pressures of closure cells. In the stress of water, the amount of $\mathrm{ABA}$ increases in the stoma cells of the plants and thus the water-insoluble starch is formed and the $\mathrm{K}^{+}$ion decreases (Okturen and Sonmez, 2005). Singh et al. (2018) stated that promising EB isolates, for use as inoculants to improve micronutrient uptake and accumulation in grains. Win et al. (2018) reported that one Pseudomonas strains (OFT5) decreased salt induced ethylene production in tomato seedlings, and although it did not diminish shoot uptake of $\mathrm{Na}$, it encouraged shoot uptake of some macronutrients and micronutrients. They proposed that the mentioned nutrients might trigger processes that lessen the effects of salt, suggesting that OFT5 can be utilized to improve nutrient uptake and plant growth under moderate salt stress condition.

Table 3. Ca, K, and Mg values obtained in drought and EB applications

\begin{tabular}{|c|c|c|c|}
\hline \multicolumn{4}{|c|}{$\mathrm{Ca}\left(\mathrm{mg} \mathrm{kg}^{-1}\right)$} \\
\hline EB & Control & Drought & Mean \\
\hline Control & $6217.4 \pm 1124.1 \mathrm{ab}^{* *}$ & $5102.8 \pm 1032.8 \mathrm{~b}$ & $5660.1 \pm 1078.4 \mathrm{~B}^{* *}$ \\
\hline CB36 / 1 & $6512.5 \pm 1101.3 \mathrm{ab}$ & $5369.4 \pm 1097.2 \mathrm{~b}$ & $5941.0 \pm 1099.9$ B \\
\hline CA41 / 1 & $6180.5 \pm 1201.6 \mathrm{ab}$ & $7603.1 \pm 1162.8 \mathrm{a}$ & $6891.8 \pm 1181.5 \mathrm{~A}$ \\
\hline Average & $6328.3 \pm 1142.5^{\mathrm{ns}}$ & $5709.4 \pm 1097.6$ & \\
\hline \multicolumn{4}{|l|}{$\mathrm{K}\left(\mathrm{mg} \mathrm{kg}^{-1}\right)$} \\
\hline EB & Control & Drought & Mean \\
\hline Control & $3518 \pm 1023^{\mathrm{ns}}$ & $2996 \pm 936$ & $3257 \pm 979$ ns \\
\hline CB36 / 1 & $3666 \pm 1501$ & $2698 \pm 969$ & $3182 \pm 1235$ \\
\hline CA41 / 1 & $3835 \pm 1432$ & $3572 \pm 1006$ & $3703 \pm 1219$ \\
\hline Average & $3641 \pm 1325 \mathrm{~A}^{* *}$ & $2992 \pm 970 \mathrm{~B}$ & \\
\hline \multicolumn{4}{|c|}{$\overline{M g}\left(\mathrm{mg} \mathrm{kg}^{-1}\right)$} \\
\hline EB & Control & Drought & Mean \\
\hline Control & $2823.0 \pm 856.9 \mathrm{bc}^{* *}$ & $2603.0 \pm 932.5 \mathrm{~b}$ & $2713.0 \pm 894.5^{\mathrm{ns}}$ \\
\hline CB36 / 1 & $3099.3 \pm 896.6$ bc & $2542.7 \pm 965.7 \mathrm{~b}$ & $2821.0 \pm 930.9$ \\
\hline CA41 / 1 & $2598.2 \pm 762.1 \mathrm{c}$ & $3285.4 \pm 1003.5 \mathrm{a}$ & $2941.8 \pm 882.6$ \\
\hline Average & $2888.6 \pm 838.5^{\mathrm{ns}}$ & $2715.4 \pm 966.8$ & \\
\hline
\end{tabular}

\section{Conclusions}

In general, drought stress affected negatively membrane damage index and leaf water content in pepper seedlings. On the other hand, EB application in the present study had some ameliorative effects on drought stressed pepper seedlings. Both EB [Bacillus thurigiensis (CA41/1) and Ochrobactrum sp. (CB36/1)] lessened substantially the membrane damage index (MDI). The MDA content of the drought stressed pepper seedlings increased significantly, but there were insignificant increases in MDA contents of EB inoculated seedlings. There were also increases in CAT and APX contents of EB inoculated seedlings. However, only CA41/1 (Bacillus thurigiensis) caused significant decreases in the mentioned enzymes in drought stressed pepper seedlings. Drought stress decreased K contents of pepper seedlings significantly. CA41/1 (Bacillus thurigiensis) inoculations caused significant increases in Ca content.

In conclusion, the effect of two endophytic bacteria varied in drought stressed pepper seedlings. Drought stress beside several abiotic stress factors is an important problem worldwide. Microbial organisms that exist in natural environments might help to increase tolerance level of plants to biotic and abiotic stress agents. Endophytic bacteria (EB) colonizing the roots and having plant growth promoting effect ameliorate plants tolerance level to the a/biotic stresses. There is a high potential of EB fighting against various stress factors in sustainable agriculture practices; however, one keeps in mind that there is variation in the performance of EB; therefore, the best EB combinations have to be determined even for cultivars in each plant species in future studies. 


\section{References}

Akkopru A. (2012). Researches on the biological control of cucumber bacterial leaf spot disease (Pseudomonas syringae pv. Lachrymans) with some root bacteria. Unpublished Ph.D. Thesis. Ege University Institute of Natural and Applied Sciences (in Turkish).

Akkopru, A., Cakar, K., \& Husseini, A. (2018). Effects of endophytic bacteria on disease and growth in plants under biotic stress. Yüzüncü Yll Üniversitesi Tarım Bilimleri Dergisi, 28(2), 200-208.

Aktas, H., Abak, K., \& Sensoy., S. (2009). Genetic diversity in some Turkish pepper (Capsicum annuum L.) genotypes revealed by AFLP analyses. African Journal of Biotechnology, 8(18), 4378-4386.

Ansary, M.H., Rahmani, H.A., Ardakani, M.R., Paknejad, F., Habibi, D., \& Mafakheri, S. (2012). Effect of Pseudomonas fluorescent on proline and phytohormonal status of maize (Zea mays L.) under water deficit stress. Annals Biol Res. 3 (2), 1054-1062.

Cakmakci, O., Cakmakci, T., Durak, E. D., Demir, S., \& Sensoy, S. (2017). Effects of arbuscular mycorrhizal fungi in melon (Cucumis melo L.) seedling under deficit irrigation. FEB-Fresenius Environmental Bulletin, 7513.

Chakraborty, U., B.N. Chakraborty, A.P. Chakraborty., \& Dey, P.L. (2013). Water stress amelioration and plant growth promotion in wheat plants by osmotic stress tolerant bacteria. World $J$ Microbiol Biotechn 29, 789-803.

Çakmakcı, T., Şahin, Ü., Kuşlu, Y., Kızıloğlu, F. M., Tüfenkçi, Ş., \& Okuroğlu, M. (2016). Van ili tarım alanlarında temiz ve atık su kaynaklarının yönetimi. Yüzüncü Yıl Üniversitesi Tarım Bilimleri Dergisi, 26(4), 662-667.

Dagdelen, N., Y1lmaz, E., Sezgin, F., \& Gürbüz, T. (2004). Effects of water stress at different growth stages on processing pepper (Capsicum annuum cv. kapija) yield, water use and quality characteristics. Pak J Biol Sci. 7(12), 2167-2172.

Dlugokecka E., \& Kacperska-Palacz, A. (1978). Re-examination of electrical conductivity method for estimation of drought injury. Biol Plantarum (Prague). 20, 262-267.

Ekinci, R., \& Başbağ, S. (2019). Kısıntılı sulamanın pamuğun (G. hirsutum L.) bazı morfolojik özelliklerine etkilerinin belirlenmesi. Yüzüncü Yıl Üniversitesi Tarım Bilimleri Dergisi, 29(4), 792-800.

Ertek, A., Sensoy, S. Gedik, I., \& Kucukyumuk, C. (2007). Irrigation scheduling for green pepper (Capsicum annuum L.) grown by field condition by using class A pan evaporation value. American-Eurasian J. Agric. Environmental Sci. 2(4), 349-358.

Fan, S., \& Blake, T. (1994). Abscisic acid induced electrolyte leakage in woody species with contrasting ecological requirements. Physiol Plantarum. 90, 414-419.

Guneri Bagci, E. (2010). Nohut çeşitlerinde kuraklı̆̆a bağl oksidatif stresin fizyolojik ve biyokimyasal parametrelerle belirlenmesi (Doktora tezi). Ankara Üniversitesi Fen Bilimleri. Ankara.403s (in Turkish).

Guzel, S., Odun, U. C., Cakmakci, T., Cakmakci, O., \& Sahin, U. (2018). The effect of cucumber (Cucumis sativus) cultivation in aquaponic and hydroponic systems on plant nutrient elements and antioxidant enzyme activity. Fresenius Environmental Bulletin, 27(1), 553-558.

Hardoim, P.R., van Overbeek, L.S., \& Dvan Elsas, J. (2008). Properties of bacterial endophytes and their proposed role in plant growth. Trends Microbiol. 16(10), 463-471.

Heath, R.L., \& Packer, L. (1968). Photoperoxidation in isolated chloroplasts: I. Kinetics and stoichiometry of fatty acid peroxidation. Archiv of Biochem Biophysics, 125(1), 189-198.

IBM, SPSS. http://www.ibm.com/tr-tr/analytics/spss-statistics-software. Available date: 10.11.2020

Jebara, S., Jebara, M., Limam., F., \& Aouani. M.E. (2005). Changes in ascorbate peroxidase, catalase, guaiacol peroxidase and superoxide dismutase activities in common bean (Phaseolus vulgaris) nodules under salt stress. J Plant Physiol. 162(8), 929-936

Kabay, T. (2014). Determination of drought and high temperature tolerant and sensitive genotypes in Van Lake Basin beans Unpublished Ph.D. Thesis. Van YYU University Institute of Natural and Applied Sciences, (in Turkish).

Kabay, T. (2018). Potasyum uygulamalarının yüksek sıcaklığa hassas fasulye genotiplerinde klorofil iyon ve enzim aktivite değişimlerine etkileri. YYU J AGR SCI, Yüzüncü Yıl Üniversitesi Tarım Bilimleri Dergisi, 28(3), 311-316. 
Kabay, T., \& Sensoy, S. (2016). Enzyme, chlorophyl and ion changes in some common bean genotypes by drought stress. YYU J AGR SCI, Yüzüncü Yll Üniversitesi Tarım Bilimleri Dergisi, 26(3), 380-395.

Kabay, T., \& S. Sensoy. (2017). Enzyme, chlorophyll and ion changes in some common bean genotypes by high temperature stress. Ege Univ J Agr Fac. 54(4), 429-437.

Kabay, T., Erdinc, C., \& Sensoy, S. (2017). Effects of drought stress on plant growth parameters, membrane damage index and nutrient content in common bean genotypes. JAPS, Journal of Animal and Plant Sciences, 27(3), 940-952.

Kacar, B. (1994). Bitki ve Toprağın Kimyasal Analizleri. Ankara Üniversitesi Ziraat Fakültesi Eğitim, Araştırma ve Geliştirme Vakfi.

Kacar, B., \& Inal. A. (2008). Plant Analysis. Nobel Yayın Dağıtım. (in Turkish).

Kohler, J., Hernández, J.A., Fuensanta Caravaca, F., \& Roldán. A. (2008). Plant-growth-promoting rhizobacteria and arbuscular mycorrhizal fungi modify alleviation biochemical mechanisms in water-stressed plants. Function Plant Biol. (35), 141-151.

Kumari, P., Meena, M., \& Upadhyay, R.S. (2018). Characterization of plant growth promoting rhizobacteria (PGPR) isolated from the rhizosphere of Vigna radiata (mung bean). Biocataly \& Agr Biotech. 16, 155-162.

Kusvuran, S., (2010). Relationships between physiological mechanisms for drought and salinity tolerance of melons. Unpublished Ph.D. Thesis. Çukurova University Institute of Natural and Applied Sciences, (in Turkish).

Kusvuran, S., \& H.Y. Dasgan. (2017). effects of drought stress on physiological and biochemical changes in Phaseolus vulgaris l. Legume Res. 40(1), 55-62.

Okturen, F,. \& Sonmez, S. (2005). Bitki besin maddeleri ile bazı bitki büyüme düzenleyicileri (hormonlar) arasındaki ilişkiler. Derim, 22(2), 20-32 (in Turkish).

Ozaktan, H., Gul, A., Cakir, B. Yolageldi, L. \& Akkopru. A. (2015). Possibilities of Using Bacterial Endophytes in Cucumber Growing as Bio Fertilizers and Biopesticides. Tubitak-COST 1110505 project (in Turkish) (COST Action FA1103: Endophytes in Biotechnology and Agriculture) p. 149.

Ozturk, K. (2002). Global climate change and its potential impact on Turkey. GU Journal of Gazi Education Faculty 22(1), 47-65 (in Turkish).

Rosenblueth, M., \& E. Martínez-Romero. (2006). Bacterial endophytes and their interactions with hosts. Mol Plant-microbe Inter. 19(8), 827-837.

Sadak, A., Akköprü, A., \& Sensoy, S. (2019). Endofit bakterilerin biber fidelerinin kurakllk stresinden geri dönüşümü üzerine etkileri. Muş Ovası Tarım Bilimleri Kongresi. Sayfa: 60-80 24-27 Eylül.

Saharan, B.S., \& Nehra. V., (2011). Plant growth promoting rhizobacteria: a critical review. Life Sci Med Res. 21(1), 30.

Sahin, U., Kuslu, Y., Kiziloglu, F. M., \& Cakmakci, T. (2016). Growth, yield, water use and crop quality responses of lettuce to different irrigation quantities in a semi-arid region of high altitude. Journal of Applied Horticulture, 18(3), 195-202.

Sairam, R. K., Srivastava, G.C., \& Saxena. D.C. (2000). Increased antioxidant activity under elevated temperatures: a mechanism of heat stress tolerance in wheat genotypes. Biol Plantarum, 43(2), $245-251$.

Sarma, R.K., \& R. Saikia. (2014). Alleviation of drought stress in mung bean by strain Pseudomonas aeruginosa GGRJ21. Plant Soil. 377, 111-126.

Sensoy, S., Ertek, A., Gedik, I., \& Kucukyumuk, C. (2007). Irrigation frequency and amount affect yield and quality of field-grown melon (Cucumis melo L.). Agricultural Water Management, 88(1-3), 269-274.

Shewfelt, R.L., \& A.C. Purvis. (1995). Toward a comprehensive model for lipid peroxidation in plant tissue disorders. HortSci. 30, 213-218.

Singh, D., N. Geat, Rajawat, M.V.S., Prasanna, R.. Kar, A., Singh, A.M. \& Saxena. A.K. (2018). Prospecting endophytes from different $\mathrm{Fe}$ or $\mathrm{Zn}$ accumulating wheat genotypes for their influence as inoculants on plant growth, yield, and micronutrient content. Annals Microbiol. 68(12), 815-833. 
Söylemez, S., Esin, Ş. \& Pakyürek, A. (2020). Waterpad polimerin farklı sulama düzeylerinde yetiştirilen patlıcanın verim ve bazı kalite özelliklerine etkisi. Yüzüncü Yıl Üniversitesi Tarım Bilimleri Dergisi, 30(2), 367-378.

Turkes, M., Sumer, U. M., \& Cetiner, G. (2000). Global climate change and its possible effects. ministry of environment, united nations framework convention on climate change, Seminar Notes, 7-24 (in Turkish),

Turkmen, O., Demir, S,. \& S. Sensoy. (2005). Effects of arbuscular mycorrhizal fungus and humic acid on the seedling growth and nutrient content of pepper grown under saline soil conditions. $J$ Biological Sci. 5 (5), 568-574.

Van Loon. (2007). Plant responses to plant growth-promoting rhizobacteria. In New perspectives and approaches in plant growth-promoting Rhizobacteria research (pp. 243-254). Springer, Dordrecht.

Win, K.T., Tanaka, F., Okazaki, K. \& Ohwaki. Y. (2018). The ACC deaminase expressing endophyte Pseudomonas spp. enhances $\mathrm{NaCl}$ stress tolerance by reducing stress-related ethylene production, resulting in improved growth, photosynthetic performance, and ionic balance in tomato plants. Plant Physiology and Biochemistry. 127, 599-607.

Yildirim, O., R. Yanmaz., \& Orta, H. (1994). Effect of different irrigation methods and irrigation regimes on pepper yield. University of Ankara. Publications of Faculty of Agriculture: 1369. Scientific Research Reports: 758. 